\title{
Health locus of control and depressive symptoms in elderly patients with type 2 diabetes
}

\author{
Umiejscowienie kontroli nad zdrowiem a objawy depresyjne u chorych na \\ cukrzycę typu 2 w podeszłym wieku
}

\author{
Monika Ewa Kowalska-Wojtysiak ${ }^{1, A-F \circledast}{ }^{\oplus}$ Małgorzata Górska-Ciebiada ${ }^{1, A, C-F \circledast \text {, }}$ \\ Agnieszka Kotarba ${ }^{1, A, E-F}$ ( \\ ${ }^{1}$ Medical University, Łódż, Poland \\ A - Research concept and design, B - Collection and/or assembly of data, C - Data analysis and interpretation, \\ $D$ - Writing the article, $E$ - Critical revision of the article, $F$ - Final approval of article
}

Kowalska- Wojtysiak M. E, Górska-Ciebiada M, Kotarba A. Health locus of control and depressive symptoms in elderly patients with type 2 diabetes. Med Og Nauk Zdr. 2020; 26(3): 254-260. doi: 10.26444/monz/122256

\begin{abstract}
Introduction. Type 2 diabetes is often comorbid with depression. Health control is thought to reside internally to the individual (Internal Locus of Control-IHLC) or externally, i.e. to other people (Powerful Others Locus of Control - PHLC), or to chance factors (Chance Locus of Control - CHLC). Knowledge of the relationships between the type of the health locus of control (LOC) and depression will allow modification of the process of psychoeducation of patients and their relatives.

Objective.The aim of the study was to assess: 1) the relationship between the type of health locus of control and occurrence of depressive symptoms in patients above 60 years of age, suffering from type 2 diabetes, 2) the incidence of depressive symptoms, 3) beliefs about the health locus of control, 4) relationships between glycated haemoglobin level, placement of health control (MHLC) and depressive symptoms (GDS-SF). Materials and method. The study was conducted on 125 patients of the outpatient diabetic clinic at the N. Barlicki University Teaching Hospital No. 1 in Łódź, by applying the Multidimensional Health Locus of Control (MHLC) Scale, the Geriatric Depression Scale-SF (GDS-SF, and the authors' own survey.
\end{abstract}

Results. Depressive symptoms were found in 40 (32\%) patients. Patients with depressive symptoms demonstrated significantly higher levels of glycated haemoglobin, and the highest scores on the Chance Locus of Control- CHLC and Powerful Others Locus of Control- PHLC scales. Patients without these symptoms achieved the highest scores on the Internal Locus of Control- IHLC and Powerful Others Locus of Control- PHLC scales.

Conclusions. The MHLC and GDS-SF scales can be useful in the holistic psychological assessment of elderly type 2 diabetics, and in planning individual education processes.

\section{Key words}

health control, depression, type 2 diabetes, late adulthood, glycated haemoglobin

\section{Streszczenie}

Wprowadzenie. Cukrzyca typu 2 często współwystępuje z depresją. Źródło sprawowania kontroli zdrowia można umiejscawiać w sobie (LOC-W), w innych (LOC-I) bądź w przypadku (LOC-P). Znajomość zależności zachodzących między typem LOC (umiejscowienia kontroli) a depresją umożliwi wprowadzenie modyfikacji w procesie psychoedukacji pacjentów i ich bliskich.

Cel pracy. Celem pracy była ocena: 1) zależności między typem LOC a obecnością objawów depresji u pacjentów po 60. r.ż. chorujących na cukrzycę typu 2, 2) częstości występowania objawów depresyjnych, 3) przekonań na temat umiejscowienia kontroli zdrowia, 4) zależności występujących między wartościami hemoglobiny glikowanej a umiejscowieniem kontroli zdrowia (MHLC) oraz objawami depresyjnymi (GDS-SF).

Materiał i metody. Badanie przeprowadzone wśród 125 pacjentów przyklinicznej Poradni Diabetologicznej USK nr 1 im. N. Barlickiego w Łodzi przy użyciu pomocy Skali Umiejscowienia Kontroli (MHLC), Geriatrycznej Skali Depresji-SF (GDS-SF) i ankiety konstrukcji własnej.

Wyniki. Objawy depresyjne stwierdzono u 40 (32\%) pacjentów. Chorzy z objawami depresyjnymi charakteryzowali się znacząco wyższym stężeniem hemoglobiny glikowanej i wykazywali najwyższe wyniki w skalach LOC-P i LOC-I, osoby bez tych objawów osiągały najwyższe wyniki w skalach: LOC-W i LOC-I.

Wnioski. Skale MHLC oraz GDS-SF mogą być przydatne w całościowej ocenie psychologicznej chorych na cukrzycę typu 2 w podeszłym wieku oraz przy planowaniu indywidualnego procesu edukacji.

\section{Słowa kluczowe}

wiek podeszły, objawy depresyjne, cukrzyca typu 2, kontrola zdrowia, hemoglobina glikowana 


\section{INTRODUCTION}

Diabetes is a serious health problem that is particularly burdensome for elderly people. This chronic somatic disease also greatly affects the mental sphere. Studies have shown that as many as $19.2 \%$ of diabetics suffer from depression, and about $56.7 \%$ of patients are diagnosed with severe emotional stress that results from the disease and its consequences $[1,2]$. It is assumed that nearly $1 / 3$ of patients with diagnosed psychological problems do not adhere to medical recommendations, which results in poorer metabolic compensation and numerous complications [3].

Health professionals as well as other people who deal with health and its promotion believe that a construct, i.e. the health locus of control (LOC), will considerably improve the condition of diabetics. This indicator may affect the patient $>$ attitude to pro-health behaviours and adherence to health recommendations, as well as the picture of the disease. A person suffering from diabetes is expected to take actions necessary to introduce changes in his/her current lifestyle. In order to do this, he/she has to be personally convinced that he/she should have specific competences necessary to achieve goals (e.g. adherence to recommendations). It is assumed that there are three loci of health control: internal locus of control (IHLC) and external locus of control, which includes chance locus of control (CHLC) and powerful others locus of control (PHLC). People demonstrating the IHLC type believe that they control their health. Such patients feel responsible for their physical and mental well-being and for the course of treatment. It is easier for them to systematically make efforts needed to follow the recommendations, which increases their chances for satisfying quality of life. Patients who score high on the CHLC scale believe that their health depends on factors which are beyond their control, such as fate, chance, fortune or misfortune. Such patients are likely to show non-adherence to treatment recommendations, more often use passive and avoidance-oriented stress coping strategies (including the challenges related to their disease) and less frequently take actions $[4,5]$.The third health locus of control is connected with "others", i.e. people who have medical knowledge and competences (PHLC). Patients demonstrating this style of control are usually disciplined and strictly follow recommendations. Such people regularly come for follow-up visits, take medications regularly and in right doses. Moreover, these patients follow their diet and get engaged in physical activity if they have been given such recommendations by medical personnel. Such an attitude positively affects the process of coping with the disease $[6,7,8]$.

Type 2 diabetes, like any other chronic disease, is a stressful experience in which emotions intensify. Depression is a reaction to a loss of control over emotional stress, which results in a lessened ability to cope with the disease. It seems reasonable to discuss the issue of depression from the perspective of Beck's cognitive theory, because despite its long history (author's first mentions of the subject come from the 1960s), it didn't lose any of its currency and still is widely quoted by the people working on issue of depression. In this model it is assumed that the emotions and behaviors are consequences of the way, in which we receive and interpret changes occurring in environment. Thus, the way a person constructs the reality, decides about its experience of emotional states and physiological and behavioral reactions. It was Beck who noticed, that negative thinking (with typical cognitive triad including critical thinking about yourself, negative evaluation of the world and the future) can cause depression and not how it was previously thought - negative thinking is only a consequence of depression. Then, necessary condition to change the way of thinking was to cure patient from the disease [9]. Besides negative thinking, main features of depression are: feeling overwhelmed, sense of hopelessness and high levels of sadness. These features are typical for patients with CHLC. Depression in diabetes requires investigation, because it is difficult to clearly determine in what sequence the diseases occur. Some authors suggest that patients with a tendency to negative thinking characterized by a lack of ability to cope with emotional stress are more likely to develop diabetes. Other researchers claim that diabetes and a need to constantly monitor your health contribute to depression in certain situations, e.g. in high levels of defensive optimism,. Moreover, studies have shown that there is a significant relationship between depressive disorders and insufficient metabolic control $[10,11]$. Some studies indicate that there is a relationship between depressive episodes and an increased level in glycated haemoglobin by as much as $1.8-3.3 \%$. This increase results from the impact of experienced emotions on secretion of neurotransmitters and hormones, which in turn can affect glucose metabolism [12]. For this reason, the need to monitor diabetes treatment through regular, annual indication of HbAlc level is strongly emphasized by PTD Recommendations. The goal achievement of good glycemic control is $\mathrm{HbAlc} \leq 7 \%(\leq 53 \mathrm{mmol} / \mathrm{mol})$ [13]. Other researchers have found that depressive symptoms increase the risk of diabetes complications and psychological factors are responsible for as many as $30-60 \%$ of cases of poor metabolic control $[14,15]$.

Research that has been conducted so far do not clearly show what type of health locus of control can be observed in elderly patients with type 2 diabetes with depressive disorders and those without depressive symptoms. As well as type of locus of control and presence of depression symptoms affect metabolic control of the disease, it is worth to verify the hypothesis about the relationship between CHCL and depression symptoms in this particular group of patients.

\section{OBJECTIVE}

This study concerns the field of medicine and health psychology. Its aim was to assess:

1) the relationship between a particular type of the health locus of control and an occurrence of depressive symptoms in patients above 60 years of age, suffering from type 2 diabetes;

2) the incidence of depressive symptoms;

3) beliefs about the health locus of control,

4) the relationship between levels of glycated haemoglobin and placement of health control (MHLC) and depressive symptoms (GDS-SF).

\section{MATERIALS AND METHOD}

The presented study is a part of a bigger project on the impact of selected psychosocial factors on metabolic compensation 
in patients above 60 years of age, suffering from type 2 diabetes. The study was conducted from March - October 2019 on patients of the outpatient diabetic clinic at the N. Barlicki University Teaching Hospital No. 1 in Łódź, with the approval of the Bioethics Committee of the Medical University of Łódź (Consent No. RNN/86/19/EC of 12 February, 2019).

The study included 125 people (73 women and 52 men) with type 2 diabetes, aged 60 years and above; mean age of all the patients -70.94 years.

The made by Yesavage et al., adapted by Servier Polska (for measuring the level of depression), the MHLC Scale by A. Wallston and R. De Vellis and adapted by Z. Juczyński (for measuring the source of health control) and the authors' own survey, regarding various aspects of life (socio-demographic data related to the disease).

The MHLC Scale by Wallston et al. is the Multidimensional Health Locus of Control (MHLC) Scale. It contains 18 statements diagnosing a person`s beliefs about his/her generalized expectations regarding the source of the health locus of control. There are three possible sources of that control:

1) internal (IHLC), where the person himself/herself controls his/her health; 2) the influence of others (PHLC), where the person's physical and mental well-being depends on the activity of other knowledgeable and competent people (mainly medical staff), and 3) external (CHLC), where the person's health is determined by chance or other external factors. The possible total number of points that can be obtained for each scale ranges from 6-36. The higher the score, the stronger the belief of the respondent that a given factor determines his/her health. The MHLC Scale used in the study was adapted to Polish conditions by Juczyński. This version is satisfactory in terms of relevance, reliability and is based on studies of various groups of patients and healthy subjects. The author of the Polish adaptation suggests that for the purpose of interpretation, obtained results should be compared with average results of the standard group or a relevant clinical group [4].

The Geriatric Depression Scale- SF, developed in 1983 by Yesavage et al. [16], is a screening tool that allows assessment of the severity of depression symptoms in elderly people. It consists of 15 questions to which two possible answers can be given ('yes' or 'no'). According to the author, obtaining six or more points on the GDS-SF Scale is identified with 'growing depression'. The maximum number of points is 15; five or less points means absence of depressive symptoms. The GDS-SF test is considered the best tool for detecting depressive symptoms in elderly patients. The authors of the scale claim it is a self-descriptive tool [17].

The tools used in this study are standardized and have been used for many years in research conducted in health protection in Poland in various age groups of patients.

The criteria for inclusion in the study were as follows: type 2 diabetes lasting for at least one year, age 60 years and above, and informed consent of the patient for inclusion in the study. Basic criteria for excluding a patient from the study were: addiction to psychoactive substances and cognitive impairment. After the patient provided an informed written consent to participate in the study, a detailed medical history was collected, cognitive impairment was excluded, and a physical examination conducted. The questionnaire used in the study included questions about the sociodemographic sphere (gender, age, place of residence, marital status) and questions about the disease (type 2 diabetes) and its course (e.g. duration of diabetes, following a diet, and performing physical exercise, assessment of knowledge about diabetes). The authors' own survey also included questions aboutthen occurrence of upsetting events in the family in the last year, sources of support, and evaluation of satisfaction with medical care. The authors also analysed the mental state of the patients using the GDS-SF Scale, and identified beliefs regarding the health locus of control using the MHLC Scale. Also evaluated were the available medical documentation and current examination results of each patient. According to the previously listed criteria, the analysed patients were divided into two groups: patients with depressive symptoms and patients without depressive symptoms (control group).

Descriptive statistics were used to analyse variables. Obtained data were presented as mean values $(\mathrm{M}) \pm$ standard deviation (SD). Distribution of the subjects was assessed using the Shapiro-Wilk test. Parameters obtained in both groups and in the control group were compared using the Student s parametric t-test, the non-parametric Mann-Whitney U test, and the Chi-square test. Statistical calculations were performed using the Statistica 13.1 programme (StatSoft, Poland), where $\mathrm{p}<0.05$ was adopted as significant.

\section{RESULTS}

Socio-demographic characteristics of patients. The presented study involved 125 people (73 women and 52 men) with type 2 diabetes, aged 60 years and above; mean age of all the patients -70.94 years, and was similar in both groups (patients with depressive symptoms - 71.50 years; patients without depressive symptoms - 70.38 years). Applied diagnostic criteria enabled the detection of depressive symptoms in 40 patients (32\%) - 23 women (57.5\%) and 17 men (42.5\%). The control group, without depressive symptoms, consisted of 85 people $(68 \%)-50$ women $(58.82 \%)$ and 35 men $(41.18 \%)$. In the group of people with depressive symptoms, $65 \%$ of the patients received support from their closest relatives/friends; a similar number of respondents from the control group (69.71\%) also received similar support. $51.79 \%$ of the patients and $57.71 \%$ of the subjects from the control group admitted to experiencing an upsetting event in the family in the last year. Patients with depressive symptoms less often followed a recommended diet or performed physical activity, were less satisfied with medical care, and less knowledgeable about diabetes.

Clinical characteristics and biochemical parameters. The average duration of diabetes in both groups was similar - 10.93 years in the depression group, and 10.96 years in the control group. Patients with depressive symptoms demonstrated significantly higher levels of glycated haemoglobin

Clinical characteristics of the patients are presented in Table 1.

Health locus of control and occurrence of depressive symptoms in patients with type 2 diabetes. Results obtained by the subjects on the MHLC Scale and GDS- SF are presented 
Table 1. Clinical characteristics of type 2 diabetic patients

\begin{tabular}{|c|c|c|c|c|}
\hline Parameter & In total & $\begin{array}{l}\text { Group with } \\
\text { depressive } \\
\text { symptoms }\end{array}$ & $\begin{array}{l}\text { Control group } \\
\text { (without } \\
\text { depressive } \\
\text { symptoms }\end{array}$ & $\mathrm{p}$ \\
\hline Adherence to diet* & $82(65.6 \%)$ & $16(40 \%)$ & 66 (77.65\%) & $\mathrm{p}<0.05$ \\
\hline Physical activity* & $57(45.6 \%)$ & $9(22.5 \%)$ & $48(56.47 \%)$ & $\mathrm{p}<0.05$ \\
\hline $\begin{array}{l}\text { Upsetting events in the } \\
\text { family }\end{array}$ & $68(54.4 \%)$ & $21(51.79 \%)$ & $47(57.71 \%)$ & \\
\hline Source of support - family & $85(68 \%)$ & $26(65 \%)$ & $59(69.71 \%)$ & \\
\hline $\begin{array}{l}\text { Level of knowledge about } \\
\text { the disease - high* }\end{array}$ & $72(57.6 \%)$ & $13(30.56 \%)$ & $59(68.85 \%)$ & $\mathrm{p}<0.05$ \\
\hline Living place - a big city & 114 (91.2\%) & $36(90 \%)$ & 79 (92.94\%) & \\
\hline $\begin{array}{l}\text { Satisfaction with medical } \\
\text { care -yes* }\end{array}$ & $104(83.2 \%)$ & $21(52.5 \%)$ & $83(97.65 \%)$ & $p<0.05$ \\
\hline $\mathrm{HbA1c}(\%)^{*}$ & $7 \pm 0.44$ & $8.23 \pm 0.44$ & $6.77 \pm 0.45$ & $\mathrm{p}<0.05$ \\
\hline $\begin{array}{l}\text { Duration of diabetes (in } \\
\text { years) }\end{array}$ & $10.95 \pm 4.87$ & $10.93 \pm 5.19$ & $10.96 \pm 4.55$ & \\
\hline
\end{tabular}

*a significant difference between the group of patients with depression and the control group $(\mathrm{p}<0.05)$; Student>s or Mann-Whitney U tests and the Chi-square test were used in order to compare the groups.

Source: the authors' own research

Table 2. Characteristics of respondents regarding the health locus of control

\begin{tabular}{lccc}
\hline Parameter & $\begin{array}{c}\text { Group with depressive } \\
\text { symptoms }\end{array}$ & $\begin{array}{c}\text { Control group (without } \\
\text { depressive symptoms) }\end{array}$ & $p$ \\
\hline IHLC & $19.65 \pm 3.86$ & $26.18 \pm 4.51$ & $<0.001$ \\
\hline CHLC & $25.87 \pm 4.31$ & $21.34 \pm 5.08$ & $<0.001$ \\
\hline PHLC & $23.56 \pm 3.31$ & $26.36 \pm 3.31$ & $<0.001$ \\
\hline GDS- SF & $9.04 \pm 1.58$ & $4.22 \pm 0.74$ & $<0.001$ \\
\hline
\end{tabular}

*a significant difference between the depression group and the control group $(p<0.05)$ Student's or Mann-Whitney U tests were used in order to compare the groups

in Table 2. Subjects with depressive symptoms obtained the lowest results on the IHLC scale (19.65), the highest results on the CHLC scale (25.87) and slightly lower on the PHLC scale (23.56). These results confirm that the patients from the studied group of respondents were mostly 'externally strong'. Results obtained by patients without depressive symptoms - high IHLC (26.18) and PHLC (26.36) and lower CHLC (21.34) - indicate that these patients believe that the chance factor is not highly determining [4].

Statistical analysis showed significant differences in results obtained on IHLC, CHLC, PHLC scales between the studied groups. Average results obtained from the examined patients with depressive symptoms in GDS-SF scale were significantly higher than results from control group.

Health locus of control, depressive symptoms and glycated haemoglobin concentration. In order to determine a relationship between the health locus of control (MHLC) and levels of glycated haemoglobin, as well as between depressiveness (GDS-SF) and levels of glycated haemoglobin, the Spearman rank correlation coefficient was calculated. Obtained results are presented in Table 3. Studies have revealed that there is a statistically significant relationship between:

- glycated haemoglobin and negative values of IHLC and PHLC, which means that the HbA1c concentration decreases with an increase in IHLC and PHLC levels;
Table 3. Spearman rank correlation coefficient between $\mathrm{HbA1c}$ and the health locus of control as well as between Hba1c and between $\mathrm{HbA} 1 \mathrm{c}$ and depressive symptoms

\begin{tabular}{lccc}
\hline Variables & $\mathrm{R}$ & $\mathrm{t}(\mathrm{n}-2)$ & $\mathrm{p}$ \\
\hline $\mathrm{IHLC}$ and HbA1c & $-0.295^{*}$ & -4.79 & $\mathrm{p}<0.001$ \\
\hline PHLC and HbA1c & $-0.225^{*}$ & -3.79 & $\mathrm{p}<0.001$ \\
\hline CHLC and HbA1c & $0.279^{*}$ & 4.32 & $\mathrm{p}<0.001$ \\
\hline HbA1c and GDS- SF & $0.509^{*}$ & 12,20 & $\mathrm{p}<0.001$ \\
\hline
\end{tabular}

*a significant correlation for $\mathrm{p}<0.05$

Table 4. Spearman correlation coefficient between depressive symptoms and LOC

\begin{tabular}{lccc}
\hline Variables & $\mathrm{R}$ & $\mathrm{t}(\mathrm{n}-2)$ & $\mathrm{p}$ \\
\hline Depression and IHCL & $-0.597^{*}$ & -7.01 & $\mathrm{p}<0.001$ \\
\hline Depression and PHLC & -0.160 & -3.49 & $\mathrm{p}<0.001$ \\
\hline Depression and CHCL & $0.389^{*}$ & 6.24 & $\mathrm{p}<0.001$ \\
\hline
\end{tabular}

* a significant correlation for $\mathrm{p}<0.05$

- glycated haemoglobin and positive values of CHLC, which means that the HbAl concentration increases with an increase in the level of CHLC;

- glycated haemoglobin and the occurrence of positive depressive symptoms, which means that an increased HbAlc level contributes to an increase in the depression level, expressed in the number of points obtained on the GDS-SF Scale.

Health locus of control and occurrence of depressive symptoms. The studied group demonstrated a significant relationship between the number of points obtained on the GDS-SF scale and IHCL and CHCL values. It was confirmed that IHLC negatively correlates with depression, i.e. the higher the PHLC, the lower the values of depressive symptoms measured by the GDS-SF Scale, whereas CHLC positively correlates with depression, i.e. higher CHLC values correspond to higher values of depressive symptoms - greater severity of depressive symptoms measured GDS-SF scale.

\section{DISCUSSION}

Diabetes is one of the main health care problems, not only in the medical but also psychological aspect $[18,19]$. It is therefore necessary to identify methods that help diabetics adapt to this chronic disease. The mental state of the patient (demonstrated, among others, in his well-being) has an impact on many aspects of coping with diabetes, including adherence to recommendations [20]. One of the most serious diseases that patients experience, particularly in late adulthood, is depression. An analysis of studies published to-date indicates that patients with type 1 and type 2 diabetes are affected by depression several times more often than the general population [2]. Some researchers have revealed that the concomitance of depression and diabetes may be associated with poorer metabolic compensation [21]. The current study confirms a high incidence of depression in diabetics - depressive symptoms were noted in as many as $32 \%$ of patients, as well as worse glycaemic control in this group of adults above 60 years of age, in comparison to subjects without depressive symptoms. 
Type 2 diabetes is a disease to which one can adapt. Adaptation to a chronic disease, however, requires the patient to change his/her behaviour and react appropriately to a difficult situation [22]. Depression impedes the process of adapting to the disease. Until now, researchers have focused on a relationship between the occurrence of depressive symptoms and the locus of control (LOC). Some authors assume that the source of LOC changes with the level of depression $[23,24]$. Naditch, et al. showed that the CHLC type favours the occurrence of depression and is comorbid with a low satisfaction with life [25]. Molinari et al. made similar observations, and noted that CHLC, depressive symptoms, and a feeling of hopelessness for the future, occurred simultaneously [26]. Fiszer et al. also observed a mutual interaction between depression and IHLC [27]. Such a relationship has not been confirmed by all authors. In the professional literature, there are reports that no relationship exists between IHLC and depression [28]. In the presented study, a correlation was found between different types of LOC and depression. It was noted that CHLC slightly dominated over PHLC in diabetic patients with depressive symptoms. This group of patients believed that their health control resides internally in medical personnel (PHLC) and depends on the chance factor (CHLC), and these values are almost equally high. It can be assumed, however, that the strength of the interaction of competent people is weakened by an equally strong belief that health control is determined by a chance factor ('externally strong' type).

The lowest (statistically significant) value in the group of patients with depressive symptoms was noted on the IHLC scale. PHLC values appeared to be the highest in patients without depressive symptoms, and the IHLC values were slightly lower in this group of patients. In this group, the lowest value was recorded on the CHLC scale. Thus, it can be concluded that subjects without depressive symptoms not only apply active coping strategies, but also adhere to recommendations received from competent personnel, which results in more effective metabolic compensation (lower levels of glycated haemoglobin.

The results obtained on the MHLC Scale indicate that patients with depressive symptoms usually tend to claim that the chance factor (CHLC) and other people (PHLC) mostly determine the source of their health control. This dependence is confirmed by a relationship between depression and CHLC and PHLC. It can be concluded that an increased level of CHLC values in diabetic patients contributes to intensification of depressive symptoms, which is demonstrated by a sense of helplessness and inability to control their own lives. Patients with high levels of CHLC do not believe they are able to face up the disease. That is why they undertake health- related behaviours less frequently and do not adhere to medical recommendations, which may lead to complications of diabetes. In consequence, they are likely to develop depression which is a response to deteriorating health. Similar results were obtained by Egede et al. who observed that what differentiates diabetics with and without depression is the LOC type, and application of health practices typical for a particular LOC type [29].

Health locus of control also correlates with adherence to medical recommendations. West et al. observed that female diabetics, demonstrating a higher PHLC level and a lower CHLC level, followed recommendations, while a lower PHLC level correlated with refusal to take medications [30]. For this reason, researchers suggested that medical personnel should take into account the patient's health locus of control when introducing medical interventions. This may translate into adherence to recommendations regarding taking medications. The current study has shown that subjects with high CHLC levels and comorbid high levels of PHLC are less likely to follow a diet and become engaged in physical activity, whereas patients demonstrating high IHLC and PHLC levels are more likely to adhere to the above recommendations. Similar reports can be found in professional literature, e.g. in a study conducted by Cierzniakowska et al., in which a high level of PHLC was observed in chronically ill patients. However, the researchers did not note a beneficial effect of this variable in adherence to recommendations in this group of patients. Bearing this observation in mind, the authors concluded that high levels of PHL C are not always a favourable phenomenon, particularly in patients over the age of 65 [31]. Miniszewska et al. have a similar opinion the high level of internal control presented by chronically ill patients may have a detrimental effect on the initiation of new pro-health behaviours by the patients [32]. Other studies also confirm that co-existing high levels of IHLC and PHLC are necessary for the initiation/modification of health-promoting behaviours. This can be explained as follows: a patient's belief in his/her own effectiveness (testified bythe high level of IHLC), and in the competence of medical staff (which can be measured by a level of IHLC, declared by the patient) is crucial for complying with medical recommendations. Wallston and Wallston (1987) pointed out in their studies that healthy people with adequate weight more often had IHLC, while PHLC favoureda better diet compliance.

Summarizing, the two sources of control is indicated PHLC and IHLC - when the state of health is satisfasctory, IHLC supports health care, whereas in the case of the illness, PHLC facilitates compliance with medical recommendations, which is a result of the faith in the competence of medical personnel [33]. The results obtained are of great practical importance. As is known, there is a two-way relationship between a patient's mental and somatic state. The mental sphere is responsible, among others, for how to deal with the disease. Here, the significance of the results obtained on the MHLC scale can be seen, on the basis of which possible obstacles to compliance with the recommendations can be identified. Patients with high CHCL levels will be less likely to follow a diet, which will result, for example, in the worsening of glycaemic control - higher HbAlc levels. If a patient with a high CHCL level has undergone the education process, it can be expected that it will be much harder for him/her to comply with the recommendation. In this sense, the MHLC scale can be a starting point select the way of leading a conversation with the patient, and the method of their education [2]. It is worth pointing out that in the current study, data was also collected on the level of satisfaction with medical care, which appears to be lower in the group of patients with depressive symptoms than in the group without depressive symptoms. This factor could, to some extent, have contributed to the non-adherence to recommendations, despite a high level of PHLC; however, this thesis requires further investigations.

The role of knowledge in the adherence to recommendations by diabetics with or without depression is unclear. Egede et al. (2008) proved that the level of knowledge about the disease was similar in patients with depressive symptoms as well as in patients without depressive symptoms [34]. In 
turn, other authors noted that patients demonstrating a high level of knowledge about type 2 diabetes more effectively followed medical recommendations, which resulted in better glycaemic control [35]. In the presented study, patients with depressive symptoms declared a subjectively low level of knowledge about diabetes, which explains why they did not adhere to recommendations regarding their diet and physical activity. This, in turn, resulted in worse glycaemic control, manifested by higher HbAlc levels.

Comorbid depression in diabetic patients correlates with poorer metabolic control and a higher incidence of diabetic complications [1]. In this study, the average percentage of HbAlc was higher in the group with depressive symptoms, and this difference was statistically significant. Besides, a strong correlation was shown between HbAlc concentration and the severity of depression (expressed in the number of points obtained on the GDS-SF Scale). However, there is a slight relationship between $\mathrm{HbAlc}$ level and the LOC type, but it is statistically significant. Thus, it seems that depressive symptoms highly contribute to a worse compensation for diabetes, whereas the LOC type is not that important. Other authors revealed a relationship between IHLC and lower levels of glycated haemoglobin. However, they believed these were associated with a greater number of mild and severe episodes of hypoglycaemia in type 1 diabetes. These researchers concluded that IHLC is the best type of locus of control to ensure good metabolic control 36].

When analysing conditions for the functioning of patients with type 2 diabet, with and without depressive symptoms, it should be remembered that the health locus of control may change in various life situations. One of them is the passing of time. Some researchers assume that in the course of time, people tend to establish their internal sense of control. Bachma and, O’Malley [37], as well as Chubb, Ertman and Ross [38], drew such conclusions from their studies. A similar relationship was found in a group of diabetics without depressive symptoms, who achieved high levels of IHLC. Moreover, it should be emphasised that the locus of control may be a variable depending on the way of experiencing difficulties; a chronic disease with uncertain prognosis and many negative consequences such as type 2 diabetes is such a difficulty. A person experiencing such a difficult life situation, may shift his/her locus of control towards CHLC [25]. It is highly probable tha loss of the ability to control own own health will contribute to depressive symptoms. Patients who receive poor results of medical examinations, despite strict adherence to recommendations, may also shift their locus of control towards CHLC. In the current study, the group of patients with depressive symptoms demonstrated a high level of CHLC, which may confirm a relationship between experiencing difficulties associated with an illness, and an increased belief that the chance factor determines their health. It should also be emphasised that in the presented study, subjects without and with depressive symptoms reported almost an equal number of upsetting events in the family in the last year, thus the variable, i.e. upsetting events in the family in the last 12 months, does not differentiate between the studied groups. It seems that the health locus of control should be systematically identified and monitored, particularly in elderly patients.

Medical personnel should have updated knowledge of the psycho-social functioning of the elderly in order to provide them properly with information about behaviour that they are required to demonstrate. It is known that education consisting only in providing information on ordered treatment and optimal management is not effective [19]. Although medical science can provide the patient with the right drugs, the patient himself/herself is almost fully responsible for achieving a satisfactory level of metabolic compensation, which is treated as a biochemical indicator of coping with the disease and recommendations. In this, one can observe the domino effect. In other words, the patient must adhere to a number of recommendations, only then, he/she will effectively and successfully control their diabetes.

It has been proved that patients with type 2 diabetes, above the age of 60 , mostly declare strong confidence in their own abilities (IHLC), and slightly lower in 'others'medical personnel (PHLC). This type of control coexisting with a high level of IHLC, may pose as a shield against developing deprssion, where as high level of CHCL might remain in correlation with the depression disorder.

Limitations. This study has several limitations:

1) it was a single-centre study, the sample size was small, therefore it must be emphasized that the conclusions should be interpreted more carefully when translated into a larger population;

2) it is realize that based on the results described in the study it is possible to analyse only the co-occurrence of variables; deeper effects of relations between depression, diabetes and MHLC could be concluded from the regression analysis.

3) the study was not designed as a longitudinal prospective investigation. It could be interesting to check how MHLC and GDS-SF may be useful in planning individual education processes for the patients. However, the study is the first in Poland to evaluate the depressive symptoms and health locus of control in patients with type 2 diabetes and to correlate it with diabetes control.

To sum up, presented study confirmed a relationship between the type of locus of control and the occurrence of depressive symptoms. It showed that patients with type 2 diabetes over the age of 60 , demonstrate a strong dependence on other people, i.e. medical personnel (PHLC). High IHLC levels may be a protective barrier against depression, whereas high CHLC and PHLC levels may correlate with depressive disorders.

Holistic care for an elderly patient with type 2 diabetes should include: identification of the LOC type, early detection of depressive disorders and constant psychological monitoring. Comprehensive care should also include components of the process of education provided for the patient and his/her relatives, involved in taking care of the sick person. The LOC type can be useful in predicting to what extent patients with type 2 diabetes will adhere to medical recommendations. Periodic monitoring of the mental state of patients by a psychologist is also advisable.

There is a need to carry out further studies in order to determine the real incidence of depressive disorders in patients with type 2 diabetes on the base of previous screening tests, with the application of the GDS-SF Scale and health loci of control, with the use the MHLC Scale. 


\section{CONCLUSIONS}

1) The incidence of depressive symptoms in patients above 60 years of age suffering from type 2 diabetes, is high - 32\%.

2) Patients with depressive symptoms have poorer glycaemic control, measured by glycated haemoglobin.

3) Patients with depressive symptoms usually believe that their health mostly depends on chance factors or on other people.

4) The MHLC and GDS-SF scales can be useful in the holistic psychological assessment of elderly type 2 diabetics, and in planning individual education processes. Patients without depressive symptoms locate them mainly in themselves

5) Patients reporting for medical check-ups are recommended to undergo regular screening tests in order to detect potential depressive symptoms, and identifying the sources of health control.

\section{Acknowledgement}

The study was financed from funds allocated to Statutory Tasks No. 503/8-072-04/503-81-001; 503-0-073-02/50381-001-17; 503/8-073-02/503-81-001-17/18; and 503-0-07302/503-81-001.

\section{REFERENCES}

1.Duda-Sobczak A, Zozulińska-Ziółkiewicz D, Wierusz-Wysocka B. Prevalence of depressive symptoms and diagnosed depression among subjects with longstanding type 1 diabetes and no serious chronic complications, hospitalized due to inadequate metabolic control of diabetes. Clin Diabetol. 2016; 5(6): 173-177. DOI: 10.5603/DK.2016.0030

2. Mućko P, Kokoszka A, Skłodowska Z. Porównanie stylów radzenia sobie z chorobą, występowania objawów depresyjnych i lękowych oraz lokalizacji poczucia kontroli u chorych na cukrzycę typu 1 i 2 . Diabetol Prakt. 2005; (6): 240-249.

3. Raebel MA, Carroll NM, Ellis JL, Schroeder EB, Bayliss EA. Importance of including early nonadherence in estimations of medication adherence. Annals of Pharmacotherapy. 2011; 45(9): 1053-60.

4. Juczyński Z. Narzędzia pomiaru w promocji i psychologii zdrowia Warszawa: Pracownia Testów Psychologicznych PTP; 2001: 72-84.

5.Sak J, Jarosz M, Mosiewicz J, et al. Postrzeganie własnej choroby a poczucie odpowiedzialności za swoje zdrowie osób przewlekle chorych. Med Ogólna i Nauki o Zdrowiu 2011; 17(4): 169-173.

6. Morowatisharifabad MA, Mahmoodabad SSM, Baghianimoghadam $\mathrm{MH}$, et al. Relationships between locus of control and adherence to diabetes regimen in a sample of Iranians. Int J of Diabetes Dev C 2010; 30: 27-32. doi:10.4103/0973-3930.60009

7.Sęk H ed. Psychologia kliniczna. Tom 1. Warszawa: Wydawnictwo Naukowe PWN; 2008: 101-118.

8. Auerbach SM, Pegg OP. Appraisal of desire for control over healthcare: structure, stability, and relation to health locus of control and to the "Big Five" personality traits. J Health Psychology. 2002; 7(4): 393-408.

9. Beck JS. Terapia poznawcza. Podstawy i zagadnienia szczegółowe. Kraków: Wyd. WUJ, 2005.

10. Warren RE, Deary IJ, Frier BM. The symptoms of hyperglycaemia in people with insulin-treated diabetes: classification using principal components analysis. Diab Metab Res Rev. 2003; 19: 408-414.

11. Talbot F, Nouwen1 A, Gingras1 J. Relations of diabetes intrusiveness and personal control to symptoms of depression among adults with diabetes. Health Psychology 1999; 18(5): 537-542.

12. Harris MD. Psychosocial aspects of diabetes with an emphasis on depression. Current Diabetes Reports 2003; (3): 49-55.

13. Polskie Towarzystwo Diabetologiczne. Zalecenia kliniczne dotyczące postępowania u chorych na cukrzycę, 2020. http://www.zaleceniaptd. viamedica.pl/1.7.2020
14. Wojtyna E. Poznawcze, afektywne i społeczne uwarunkowania stosowania się do zaleceń lekarskich przez chorych na cukrzycę typu 2. Praca doktorska, Katowice 2011.

15. Korzon-Burakowska A, Adamska K. Psychologiczne aspekty leczenia cukrzycy. Diabetologia Polska 1998; (4): 238-242.

16. Yesavage JA, Brink TL, Rose TL, Lum O, Huang V, Adey M, Leirer VO. Development and validation of a geriatric depression screening scale: A preliminary report. Journal of Psychiatric Research 1982; 17(1):37-49. Doi.org/10.1016/0022-3956(82)90033-4

17. Albiński R, Kleszczewska-Albińska A, Bedyńska S. Geriatryczna Skala Depresji (GDS). Trafność i rzetelność różnych wersji tego narzędzia przegląd badań Geriatric Depression Scale (GDS). Psychiatria Polska 2011, tom XLV, (4): 555-562.

18. Global status report on noncommunicable diseases 2010. Geneva: World Health Organization; 2011.

19. Tatoń J, Czech A, Bernas M. Diabetologia kliniczna. Warszawa: Wydawnictwo Lekarskie PZWL; 2008.

20. Polskie Towarzystwo Diabetologiczne. Zalecenia kliniczne dotyczące postępowania u chorych na cukrzycę, 2019. Diabet Klin. 2019; 7Postępowanie psychologiczne w cukrzycy.

21.Lustman PJ, Anderson, RJ, Freedland1 KE, de Groot M, Carney RM, Clouse RE. Depression and poor glycemic control. Diabetes Care 2000; 23: 934-942.

22. Basińska MA, Zalewska-Rydzkowska D, Junik R, Skibicka M. Przewidywanie stosowania się do zaleceń dietetycznych przez chorych na cukrzycę typu 1 - związek z umiejscowieniem kontroli zdrowia. Diabetologia Praktyczna 2007; 8(11): 419-424.

23. Rotter JB. Poczucie wewnętrznej versus zewnętrznej kontroli wzmocnień. Nowiny Psychol. 1990; 5-6: 59-70.

24. Abramowitz SI. Locus of control and self-reported depression among college students. Psychol Rep. 1969; 25: 149-150.

25. Kościelak R. Poczucie umiejscowienia kontroli i przekonania o własnej skuteczności w zdrowiu i chorobie. Oficyna Wydawnicza Impuls, Kraków; 2010. p. 37-57.

26. Molinari V, Khanna P. Locus of control and its relationship to anxiety and depression. J Pers Assess. 1981; (45): 314-319.

27. Fiszer K, Sobów T. Związek umiejscowienia kontroli zdrowia z depresyjnością wśród studentów uczelni medycznej. Medycyna Ogólna i Nauki o Zdrowiu 2013; 19(3): 294-299.

28. Vandervoort DJ, Luis PK, Hamilton SE. Some correlates of health locus of control among multicultural individuals. Curr Psychol. 1997; 16(2): 167-178.

29. Egede LE, Zheng D. Independent factors associated with major depressive disorder in a national sample of individuals with diabetes. Diabetes Care 2003; 26: 104-11.

30. West LM, Borg TR, Cordina M. Health locus of control: Its relationship with medication adherence and medication wastage. Res Social Admin Pharm. 2018 Nov; 14(11): 1015-1019.

31. Cierzniakowska K, Kozłowska E, Popow A, Mościcka P, Cwajda-Białąsik J. Czynniki determinujące umiejscowienie kontroli zdrowia u osób chorych i zdrowych. Pielęg Chirurgiczne i Angiologiczne 2018; 2: 44-50.

32. Miniszewska J, Juczyński Z, Ograczyk A, Zalewska A. Health-related Quality of Life in Psoriasis: Important Role of Personal. Resources. Acta Derm Venereol. 2013; 93: 551-556.

33. Rosińska P. Poczucie własnej skuteczności i lokalizacja kontroli zdrowia jako predykatory troski o zdrowie w grupie matek małych dzieci. In: Kwartalnik Naukowy Fides Et Ratio. 4(32) 2017. p. 113-142.

34. Egede LE, Ellis C. The effects of depression on diabetes knowledge, diabetes self-managemen, and perceived control in indigent pateints with type 2 diabetes. Diabetes Technol Ther. 2008 Jun; 10(3): 2013-9. https://doi.org/10.1089/dia

35. Indelicato L, Mariano V, Galasso S, Boscari F, et al. Influence of health locus of control and fear of hypoglycaemia on glycaemic control and treatmen satisfaction in people with Type 1 diabetes on insulin pum therapy. Diabet Med. 2017; 34(5): 691-697.

36. Bachman JG, O'Malley PM, Cairns E, McWhirter L, Duffy U, Barry R. The stability of selfconcept in late adolescence: Gender and situational effects. Pers Individual Differences 1990; 11: 937-944.

37. Chubb NH, Fertman CI, Ross JL. Adolescent self-esteem and locus of control. A logitudinal study of gender and age differences. Adolescence 1997; 32(125): 113-129. 